\title{
Message to the caregivers: communicating to patients on hand hygiene improves your practices!
}

\author{
D Verjat-Trannoy*, M-A Ertzscheid, S Monier, N Jouzeau, D Zaro-Goni, P Astagneau, \\ From behalf the GHRYM workshop \\ From 3rd International Conference on Prevention and Infection Control (ICPIC 2015) \\ Geneva, Switzerland. 16-19 June 2015
}

\section{Introduction}

Since 2012, in order to improve caregivers-to-patient information and awareness about hand hygiene ( $\mathrm{HH})$, a communication campaign has been launched in healthcare facilities (HCF). The patients have been systematically informed of practices which are recommended during cares.

\section{Objectives}

To identify and characterize changes in caregivers $\mathrm{HH}$ practices after patient information.

\section{Methods}

In 2013 and 2014, an evaluation of caregivers $\mathrm{HH}$ changes was proposed to voluntary HCF. In the participating services, reporting was organized for caregivers using standardized questionnaire including different $\mathrm{HH}$ possible changes: better $\mathrm{HH}$ compliance, systematic use of handrub products, withdrawing hand jewelry.

\section{Results}

A total of 22 HCF participated in the study. The questionnaire was completed by 269 caregivers (115 nurses, 105 nurses aides and 49 others professions), of whom $32 \%$ declared no need to change because they were already following recommendations and $49 \%$ reported having changed at least one practice. No change in $\mathrm{HH}$ practices was declared by $18 \%$ of the caregivers. Among caregivers who changed their HH practices $(n=132), 63 \%(n=83)$ used more systematically handrub products, $58 \%(\mathrm{n}=76)$ increased their $\mathrm{HH}$ compliance and $34 \%(\mathrm{n}=45)$ withdrew their hand jewelry. The global proportion of $\mathrm{HH}$ changes

French Healthcare Associated Infection Control Network (CClin-Arlin), France was not different in nurses and aides but differences were found by profession for the reported changes.

\section{Conclusion}

After the patient information on hand hygiene, half of participating caregivers have declared a change in their $\mathrm{HH}$ practices. However, the sustainability of the changes remains to be verified. This study could be supplemented by observations of practice or a measure of the hand-rub consumption to confirm these encouraging results.

\section{Disclosure of interest}

None declared.

Published: 16 June 2015

doi:10.1186/2047-2994-4-S1-P292

Cite this article as: Verjat-Trannoy et al:: Message to the caregivers: communicating to patients on hand hygiene improves your practices! Antimicrobial Resistance and Infection Control 2015 4(Suppl 1):P292.

Submit your next manuscript to BioMed Central and take full advantage of:

- Convenient online submission

- Thorough peer review

- No space constraints or color figure charges

- Immediate publication on acceptance

- Inclusion in PubMed, CAS, Scopus and Google Scholar

- Research which is freely available for redistribution 